\title{
Towards the recognition of diversity: Muslim marriages in South Africa*
}

Pieter Bakker

$B L C L L B L L D$

Associate Professor, University of South Africa

\section{OPSOMMING}

Op pad na erkenning van diversiteit: Moslemhuwelike in Suid-Afrika

Die Grondwet van die Republiek van Suid-Afrika bevorder die waardes van menswaardigheid, gelykheid en vryheid in 'n multikulturele samelewing. Die artikel ondersoek hoe Moslemhuwelike binne die Suid-Afrikaanse grondwetlike bedeling erken kan word. Die skrywer voer aan dat daar geen werklike rede bestaan waarom Moslemhuwelike nie erken kan word nie. Die enigste argument teen die bestaan van sodanige huwelike is moontlik dat Moslemhuweliksreg partriargaal van aard is en daarom diskrimineer op grond van geslag. Die skrywer argumenteer verder dat die Moslemhuweliksreg nie noodwendig strydig sal wees met die handves van regte as 'n multikulturele benadering tot menseregte gevolg word nie.

\section{INTRODUCTION}

The preamble to the South African Constitution of 1996 states: "[W]e, the people of South Africa... [b]elieve that South Africa belongs to all who live in it, united in our diversity".

"[U]nited in our diversity" seems to be a contradictio in terminis. How can a society be united and diverse at the same time? However, it can mean that South Africans are united because they acknowledge each other's diversity. Which in turn implies that too much emphasis must not be placed on either unity or diversity during the interpretation of the Constitution. ${ }^{1}$

The South African Constitution, in its Bill of Rights, promotes the values of dignity, equality and freedom in a multi-cultural society. ${ }^{2}$ The Constitution enshrines equal protection before the law. ${ }^{3}$ The right to equality prohibits unfair discrimination by the state or any person on the grounds, amongst others, of gender, ethnic or social origin, sexual orientation, religion, belief or culture. ${ }^{4}$ Section 13 which deals with the right to freedom of religion, belief and opinion

* This article is based on a paper delivered at the 8th International Conference on Diversity in Organisations, Communities \& Nations in Montréal, Canada on 17 June 2008. The article was published in 2008 (8) International Journal of Diversity in Organisations, Communities \& Nations available, subject to restrictions, online at http://www.DiversityJournal.com.

1 Venter "Die betekenis van die bepalings van die 1996 Grondwet" 1998 (1) PER http://www.puk.ac.za/fakulteite/regte/per/issues.html (accessed on 28/05/2008).

2 The Constitution of the Republic of South Africa, 1996.

3 S 9(1).

$4 \mathrm{~S} 9(3)$. 
provides for legislation recognising marriages and/or personal and family law systems concluded under a system of religious, personal or family law. ${ }^{5}$ Recognition is nevertheless limited by an internal limitation clause. Recognition of such a marriage or personal law system must be consistent with the Bill of Rights and the rest of the Constitution. ${ }^{6}$

The legislature is endeavouring to acknowledge diversity in South Africa. The nature of marriage has been changed fundamentally. Prior to the Bill of Rights ${ }^{7}$ only one form of marriage was recognised, that is, civil marriage concluded in terms of the Marriage Act. ${ }^{8}$ Limited recognition was provided for indigenous marriages for specific purposes ${ }^{9}$ and religious marriages were not recognised. ${ }^{10}$ Currently there are three different forms of marriage in South Africa:

(a) Civil marriage concluded in terms of the Marriage Act. Civil marriage is a monogamous heterosexual marriage. ${ }^{11}$

(b) Customary marriage concluded in terms of the Recognition of Customary Marriages Act. ${ }^{12} \mathrm{~A}$ customary marriage is a marriage based on the traditions of the indigenous people of South Africa. ${ }^{13}$ A customary marriage is a polygynous ${ }^{14}$ heterosexual marriage. ${ }^{15}$

5 S $13(3)(a)$

6 S $13(3)(b)$.

7 Contained in the Interim Constitution 200 of 1993 and the Final Constitution of the Republic of South Africa, 1996.

825 of 1961.

9 Bekker and Maithufi "The dichotomy between 'official customary law' and 'non official customary law"" 1992 TRW 54; Bekker "How compatible is African customary law with human rights? Some preliminary observations" 1994 THRHR 443; Prinsloo "Regterlike harmoniëring van die Suid-Afrikaanse reg en die inheemse reg" 1994 TSAR 843; Labuschagne "Spanningsveld tussen die psigo-kulturele en juridiese" 1995 THRHR 303; Maithufi "Customary law of marriage and a bill of rights in South Africa: Quo vadis?" 1996 THRHR 298; Pieterse "Killing it softly: Customary law in the new constitutional order" 2000 De Jure 36; Bonthuys and Pieterse "Still unclear: the validity of certain customary marriages in terms of the Recognition of Marriages Act" 2000 THRHR 618; Maithufi "The Recognition of Customary Marriages Act of 1998: A commentary" 2000 THRHR 509; De Koker "Proving the existence of an African customary marriage" 2001 TSAR 257.

10 Prinsloo "Pluralism or unification in family law in South Africa?" 1990 CILSA 324; Cachalia "Citizenship, Muslim family law and a future South African constitution" 1993 THRHR 398; Maithufi 1996 THRHR 298; Sinclair The Law of Marriage Vol 1 (1996) 164, 215; Maithufi and Moloi "The current legal status of customary marriages in South Africa" 2002 TRW 600.

11 Hyde v Hyde \& Woodmanse (1866) LR 1 P\&D 130; Seedat's Executors v The Master (Natal) 1917 AD 302; Ismail v Ismail 19831 SA 1006 (A).

12120 of 1998

13 S 1(iii).

14 Only a plurality of wives is allowed.

15 Oomen "Traditional woman-to-woman marriages, and the Recognition of Customary Marriages Act" 2000 THRHR 274, argues in favour of the recognition of a same-sex marriage under the Recognition of Customary Marriages Act. Contrary to this argument see Van Schalkwyk "Law reform and the recognition of human rights within the South African family law with specific reference to the Recognition of Customary Marriages Act, 120 of 1998, and Islamic marriages" 2003 De Jure 293 and Bakker "Bestaanbaarheid van bigamie as misdryf in 'n kulturele heterogene samelewing" 2006 THRHR 64. 
(c) Civil union concluded in terms of the Civil Union Act. ${ }^{16}$ The Act makes provision for the conclusion of a hetero- or same-sex monogamous union. ${ }^{17}$ The partners to a union can decide whether they want to call their union a civil partnership or a marriage. ${ }^{18}$ The consequences are the same as that of a civil marriage concluded in terms of the Marriage Act. ${ }^{19}$ The difference between a civil union and a civil marriage is that the Civil Union Act provides for same-sex marriages and provides for the partners to a civil union to decide whether they want to call their union a marriage or a partnership.

The South African Law Commission (currently the South African Law Reform Commission) compiled a draft Muslim Marriages Bill in 2003. ${ }^{20}$ Strong opposition was received from predominantly male religious groups, feminists and $\mathrm{Hu}-$ man Rights groups. The religious groups argued that Islamic law is divine law and cannot be altered by temporal law. Feminist and human rights groups argued that Islamic law is in direct conflict with the Bill of Rights. The proposed draft bill has not as yet been tabled in Parliament.

This article investigates whether Muslim marriages may be recognised within the constitutional structure of South Africa.

\section{CURRENT RECOGNITION OF MUSLIM MARRIAGES}

Muslim marriages are regarded in the same way as indigenous marriages prior to the Recognition of Customary Marriages Act. ${ }^{21}$ Indigenous marriages were not recognised because they allowed polygyny and where not solemnised in terms of the Marriage Act. $^{22}$ The same objections are advanced for the non-recognition of Muslim marriages. ${ }^{23}$ The consequences of Muslim marriages are recognised in specific circumstances even though the Muslim marriage as an institution is not recognised. ${ }^{24} \mathrm{~A}$ further argument for non-recognition is that the patriarchal nature of Muslim marriages is in conflict with the right to equality. ${ }^{25}$

Regardless of the above arguments Muslim marriages are recognised for certain purposes by legislation and the courts.

1617 of 2006. Date of commencement 30 November 2006.

17 From the definition of "civil union" in s 1 read with s 8(1) it is clear that a civil union is monogamous in nature. The Act does not expressly state that provision is made for heteroand same-sex unions, however the preamble of the Act refers to same-sex marriage; s 6 provides that a marriage officer has a choice whether or not he/she will conclude same-sex unions and s 8(6) states that "[a] civil union may only be registered by prospective civil union partners who would, apart from the fact that they are of the same sex, not be prohibited by law from concluding a marriage under the Marriage Act or Customary Marriages Act".

$18 \mathrm{~S} 11(1)$.

$19 \mathrm{~S} 13(1)$.

20 Report on Project 106 Islamic marriages and related matters (2003) Appendix A.

21 The Act came into operation on 20 November 2000.

22 Hahlo The South African law of husband and wife (1985) 31; Cronjé and Heaton South African family law (2004) 215.

23 Bronn v Fritz Bronn's Executors 1860 Searle 313; Hyde v Hyde 1886 LR 1 P\&D 130; Ebrahim v Mohamed Essop 1905 TS 59; Seedat's Executors v The Master (Natal) 1917 AD 302; Estate Metha v Acting Master, High Court 19584 SA 252 (FC); Osman v Osman 19832 SA 706 (D); Ismail v Ismail 19831 SA 1006 (A) 1024E-F.

24 Ismail v Ismail 20074 SA 557 (E) 561C-E.

25 Ismail v Ismail $19831 \mathrm{SA} 1006$ (A) 1025G-H. 
The following Acts recognise religious marriages: the Children's Act 38 of 2005; the Births and Deaths Registration Act 51 of 1992; Domestic Violence Act 116 of 1998; Demobilisation Act 99 of 1996; Special Pensions Act 69 of 1996; Criminal Procedure Act 51 of 1977; Civil Proceedings Evidence Act 25 of 1965; Pension Fund Act 24 of 1956; and the Insolvency Act 24 of $1936 .^{26}$

After the coming into effect of the 1996 Constitution the courts became more sympathetic towards the predicament of spouses in a Muslim marriage. Certain consequences of Muslim marriages were recognised, but not Muslim marriage as an institution.

In Ryland $v$ Edros $^{27}$ the court enforced parts of a Muslim marriage contract in a de facto monogamous Muslim marriage. The court however did not state whether such a contract will be enforced where the marriage is polygynous.

The Supreme Court in the Amod case ${ }^{28}$ extended the dependent's action for loss of support to the surviving spouse in a monogamous Muslim marriage.

In Daniels $v$ Campbell ${ }^{29}$ the meaning of the word "spouse" in the Maintenance of Surviving Spouses Act $^{30}$ was extended to include a spouse from a monogamous Muslim marriage.

Khan $v \operatorname{Khan}^{31}$ was the first case to expressly state that if the consequences of a de facto monogamous Muslim marriage are recognised, then the consequences of a polygynous Muslim marriage should also be recognised. The court states that in light of the Recognition of Customary Marriages Act, which recognises polygynous marriages entered into before the Recognition of Customary Marriages Act was promulgated, it would be a gross violation of the party's rights to equality to deny a maintenance claim in terms of the Maintenance $\mathrm{Act}^{32}$ based on the fact that the Muslim marriage was de facto polygynous. ${ }^{33}$

26 S 1 of the Children's Act 38 of 2005, dealing with the protection of the rights of a child, defines "marriage" to include a marriage in accordance with "a system of religious law". The words "husband", "wife", "widower", "widow", "married person" and "divorced person" must be construed in accordance with the above approach. The Domestic Violence Act 116 of 1998 protects members in a domestic relationship against acts of violence. According to the Act "domestic relationship" includes marriages concluded in terms of "any law, custom or religion". In terms of the Demobilisation Act 99 of 1996 "dependent" includes a surviving spouse "in accordance with tenets of a religion". The special Pensions Act 69 of 1996 which provides for the payment of a pension or survivor benefit in certain instances recognises marriages in terms of any tenets of religion in terms of s 31. In terms of the Births and Deaths Registration Act 51 of 1992 "marriage" includes all marriages in accordance with "tenets of any religion". S 195(2) of the Criminal Procedure Act 51 of 1977 and s 10A of the Civil Proceedings Evidence Act 25 of 1965 recognise religious marriages for the purposes of compelling a spouse as a witness in criminal and civil proceedings. In terms of S 21(3) of the Insolvency Act 24 of 1963 "spouse" in the Act includes a person married in accordance with any law or custom. According to the Pension Fund Act 24 of 1956 a "dependent" includes a spouse married under the tenets of any Asiatic religion.

2719972 SA $690(\mathrm{C})$.

28 Amod v Multilateral Motor Vehicle Accidents Fund 19994 SA 1319 (SCA).

2920045 SA 331 (CC).

3027 of 1990.

3120052 SA $272(\mathrm{~T})$.

3299 of 1998.

33 In Hassan v Jacobs (case no 5704/2004 (C) unreported) the court indicated that it is clear from legislative and judicial policy that public policy towards polygynous marriages has continued on next page 
Since the promulgation of the Recognition of Customary Marriages Act it is unfair discrimination to deny other cultural and religious groups the right to marry by merely arguing that the marriage was not concluded in terms of the Marriage Act. Why should religious marriages be treated differently than customary marriages? In the light of the Khan case and the fact that the Recognition of Customary Marriages Act recognises de facto polygynous marriages it cannot be argued that polygynous marriages are against the moral conviction of the South African community. The only valid argument against the recognition of Muslim marriages is that Islamic family law infringes on the right to equality and dignity by discriminating against women, due to the patriarchal nature of Islamic law.

\section{HUMAN RIGHTS ISSUES}

The strongest argument that can be advanced against the recognition of Muslim family law is that Muslim family law, due to its patriarchal nature discriminates on the grounds of sex and gender and is therefore in direct conflict with the Bill of Rights. ${ }^{34}$

The right to freedom of religion is however subordinate to other rights in the Constitution due to an internal limitation clause. For a religious or cultural personal law system to be recognised it has to be consistent with the Bill of Rights and the rest of the Constitution. ${ }^{35}$ It can be argued that the limitation on the right to gender equality is reasonable and justifiable in terms of the general limitation clause of the Constitution. Such an argument might succeed if it is argued that women will be in a far worse position if their marriages are not recognised.

However, there is another approach. The universalism versus cultural relativism debate in international human rights law indicates that there might not always be a conflict between freedom of religion and sex and gender equality if viewed from another perspective than that of a western scholar.

The universalism versus cultural relativism debate relates to the interpretation and application of human rights. ${ }^{36}$ A strict universalist approach is advocated mainly by western scholars. ${ }^{37}$ This approach implies that human rights are the same in application and substance throughout the world. ${ }^{38}$ Oppiste to this approach is cultural relativism. This approach is usually supported by non-western scholars or scholars belonging to minority groups. ${ }^{39}$ Cultural relativism implies that human rights are not exclusively western in origin but are inherent in human nature and based on morality. Morality is affected by historical, political, economic, social, cultural and religious factors. Therefore, human rights principles

changed and that it would be discriminatory to exlude Muslim spouses in polygynous marriages from the application of the Intestate Succession Act 81 of 1987 and the Maintenance of Surviving Spouses Act 27 of 1990 (paras 18-19). The decision was referred to the Constitutional Court in terms of s 167(5) of the Constitution in regard to the constitutionality of the Intestate Succession Act and Maintenance of Surviving Spouses Act.

34 Cronjé and Heaton 222.

$35 \mathrm{~S} 13(3)$ of the Constitution.

36 Universalism is an aspect of the universalisation of human rights.

37 Baderin International human rights and Islamic law (2003) 26.

38 Ibid.

39 Idem 27. 
have to be construed with reference to these factors and cannot exist in a vacuum. This implies that the current approach to human rights is based on a western concept of dignity and cannot be applied in the same way in non-western legal systems. ${ }^{40}$

There are deficiencies in both theories. Cultural relativism can lead to serious human rights abuses, when the content of human rights is diluted by cultural excuses. Universalism on the other hand merely portrays the western concept of human rights and is not truly universal, but is in effect cultural relativism. In the eyes of non-western scholars universalism is used in the same way as the repugnancy test was used under colonialism. The main purpose thereof was to rid countries of their offensive indigenous and religious laws. The consequence of universalism is thus "a form of neo-colonialism through human rights instruments".

A median between the two approaches is proposed by Baderin. ${ }^{41}$ Universal acceptance of human rights demands a truly cross-cultural or multi-cultural approach to the interpretation and application of human rights principles:

"Presumptions of cultural inferiority must be avoided and justifications on cultural differences must be examined and critically evaluated within the parameters of human dignity with a view to evolving an inclusive universalism in international human rights law." ${ }^{42}$

When approaching Muslim family law without a preconceived Western condemnation of Muslim culture and a true understanding of the Muslim religion it becomes clear that not all the religious rules regarding Muslim marriages are discriminatory in nature. If a rule is however discriminatory it would be advisable to develop such a rule in accordance with the Bill of Rights in the same way it is currently done with the common law and customary law instead of striking down the rule and leaving a void in Muslim family law. A good example of how a cross-cultural approach can be applied by courts is the case of Mthembu v Let$\operatorname{sela}^{43}$ which dealt with the male primogeniture rule in customary law. In accordance with this rule only a direct male descendent may inherit. The court was approached to declare the principle of primogeniture unconstitutional due to its discriminatory nature towards women. The court indicated that even though the rule is prima facie discriminatory it does not unfairly discriminate on the ground of sex:

"The devolution of the deceased's property onto the male heir involves a concomitant duty of support and protection of the woman or women to whom he was married by customary law and of the children procreated under the system and belonging to a particular house." 44

The underlying reason for male primogeniture is that it provides for the support and protection of women and children in the deceased's household and the continuation of the family unit. Unfortunately the rule of male primogeniture was declared unconstitutional and invalid by the Constitutional Court in the Bhe-

40 Ibid.

41 Idem 23-29

42 Idem 29.

4319972 SA 936 (T); 19982 SA 675 T and 2000 (3) SA 867 (SCA). For a discussion of these cases see Bekker "Inheemse reg - 'n pleidooi vir die ontwikkeling van 'n nuwe jurisprudensie" 2006 THRHR 529.

44 Mthembu v Letsela 19972 SA 936 (T) 946B-C. 
case. $^{45}$ The approach of the Constitutional Court received a fair amount of criticism from some and also praise from others. ${ }^{46}$

The application of a cross-cultural approach can be illustrated by the principle of maintenance upon divorce in Islamic family law. A divorced Muslim wife is not entitled to maintenance after her iddah. ${ }^{47}$ This might seem discriminatory in nature, but if it is considered that a Muslim wife is entitled to deferred mahr upon divorce and the fact that her husband was under an obligation to maintain her during the subsistence of the marriage regardless of her own income, it can be argued that such discrimination might not be unfair. Deferred mahr can be equated to lump sum maintenance and she is therefore entitled to indirect maintenance after her iddah regardless of whether or not she earned an income during the subsistence of the marriage. The scope of this article is not to evaluate all the rules of Islamic family law against the South African Constitution, but merely to provide an indication that the human rights approach to religious and cultural law should be revisited.

\section{THE DRAFT MUSLIM MARRIAGES BILL}

I will give a short breakdown of the Draft Muslim Marriages Bill. Even though further progress has not been made since the Draft Bill was proposed in July 2003, the Draft Bill is a fair example of a pluralistic approach to the recognition of religious marriage law. There are of course also quite a few issues in the Bill which need more clarification.

The Draft Muslim Marriages Bill recognises all Muslim marriages entered into before or after the commencement of the Act. A Muslim marriage entered into after the commencement of the Act will have to comply with the requirements for a valid marriage in accordance with the Act, if the parties opted that the Act should be applicable to their marriage. ${ }^{48}$ Parties to existing civil marriages will also have the option to elect that the provisions of the Act should be applicable to their marriage. ${ }^{49}$ The reason for the "opt-in"-clause is that most Muslims in South Africa enter into a Muslim marriage and shortly thereafter enter into a civil marriage. This is done to ensure that their relationship is recognised as a valid marriage. The spouse will then be provided with an opportunity to elect that only Muslim marriage law should be applicable to their marriage.

Parties to a Muslim marriage before the commencement of the Act have the option to elect within a prescribed time that the Act should not apply to them. ${ }^{50}$ If

45 Bhe v Magistrate Khayelitsha; Shibi v Sithole; South African Human Rights Commission v President of the Republic of South Africa 20051 SA 580 (CC). See also Bhe v Magistrate Khayelitsha 20042 SA 544 (C).

46 Himonga "The advancement of African women's rights in the first decade of democracy in South Africa: The reform of the customary law of marriage and succession" 2005 Acta Juridica 82; Knoetze and Olivier "To develop or not to develop the customary law: That is the question in Bhe" 2005 Obiter 126; Van Niekerk "Succession, living indigenous law and ubuntu in the Constitutional Court" 2005 Obiter 474; Bekker 2006 THRHR 529; Rautenbach, Du Plessis and Pienaar "Is primogeniture extinct like the Dodo, or is there any prospect of it rising from the ashes? Comments on the evolution of customary succession laws in South Africa" 2006 SAJHR 99.

47 Waiting period of three months after or during divorce.

$48 \mathrm{~S} 2(1)$.

49 S 2(4).

50 S 2(2). 
the parties elect to opt out of the application of the Act the current position will apply. ${ }^{51}$ Only limited recognition for certain purposes will be afforded to marriages where the spouses opt-out.

The requirements for a valid Muslim marriage are broadly in accordance with the Marriage Act. It deals mainly with the marriageable age and consent. ${ }^{52} \mathrm{~A}$ Muslim marriage will automatically be to the exclusion of all property and accrual, unless the proprietary consequences are regulated by an antenuptial contract. ${ }^{53}$ The Draft Bill recognises polygyny but limits its application. ${ }^{54}$ Where a man wants to enter into a second or further Muslim marriage he will have to apply to the court for approval of a contract which will regulate the future matrimonial property system for all his marriages. ${ }^{55}$ On application the court will further need to investigate whether the husband will be able to maintain his wives equally. ${ }^{56}$

The Draft Bill recognises most Islamic grounds for divorce. ${ }^{57}$ Automatic termination due to the change of one of the spouses' religion is however not recognised by the Draft Bill. All forms of talaq are recognised. ${ }^{58}$ The Draft Bill only requires that the talaq has to be confirmed by the court. ${ }^{59}$ From this it is evident that the marriage is terminated by talaq and not the court order. The court order is merely declaratory in nature. The only limitation placed on talaq is the requirement that a talaq must be registered. It is unclear from the Draft Bill whether failure to register the irrevocable talaq will lead to the invalidity thereof. The parties can terminate their marriage by agreement (khula) and a woman may terminate the marriage by way of a court application (faskh). ${ }^{60}$ A Muslim marriage may be dissolved by a court order on any ground of divorce in Islamic law. ${ }^{61}$

$51 \mathrm{~S} 2(3)$

52 An interesting aspect is that marriage by proxy is allowed, however the marriage officer will have to ascertain from the proxy whether the bride consents. Another controversial aspect is that witnesses as required by Islamic law have to be present at the conclusion of the marriage.

53 S 8(1). Civil marriages and customary marriages entered into after the promulgation of the Recognition of Customary Marriages Act are automatically in community of property, unless the parties entered into an antenuptial contract.

54 S 8(6).

55 A similar clause is contained in the Recognition of Customary Marriages Act.

$56 \mathrm{~S} 8(7)$

$57 \mathrm{~S} 9(2)$.

58 S 9(3) read with the definitions in the Draft Bill of "talaq", "irrevocable talaq" and "tawid al-Talaq". The forms are the talaq al-ashan; talaq al-hasan; talaq al-bida; tawid al-talaq. Talaq al-ashan and Talaq al-hasan are both forms of the Talaq as-sunna. The Talaq alashan is pronounced once during the wife's thur cycle, iddah (waiting period) starts immediately and the marriage dissolves immediately after iddah. This is the most acceptable form of talaq. The talaq al-hasan is pronounced in the wife's thur cycle and then in each thur cycle during iddah. The marriage is terminated at the end of iddah. Talaq al-bida is the most reprehensible form of talaq. The talaq does not comply with the requirements of the talaq as-sunna due to some form of deficiency. It is however still a valid form of divorce. The marriage is terminated immediately after pronunciation and cannot be recalled during iddah. Tawid al-Talaq where the husband has delegated use of talaq to his wife.

59 S 9(3)(f).

60 Ss $9(4)$ and (5).

61 Including "discord between the spouses has undermined the objects of marriage, including foundational values of mutual love, affection, companionship and understanding ..."

continued on next page 
The Draft Bill requires the registration of the marriage and the mahr agreement. ${ }^{62}$ Registration is not a prerequisite for a valid marriage. ${ }^{63}$

The Law Commission's approach to the recognition of Islamic marriage law is based on a pluralistic model. ${ }^{64}$ The requirements for the conclusion of a Muslim marriage are to a large extent similar to the requirements contained in the Marriage Act. As far as patrimonial consequences are concerned, grounds for dissolution and the consequences of divorce are based on Muslim family law and will therefore introduce a new official form of marriage law in the South African family law system should it be passed into law. ${ }^{65}$

A drawback to the Draft Bill is that it does not clearly state whether Muslim personal law will be applicable to Muslim marriages.

\section{APPLICATION OF MUSLIM PERSONAL LAW}

In South Africa Muslim personal law does not enjoy the same recognition as customary law. ${ }^{66}$ Customary law is recognised on the same level as the common law, whereas no official recognition of Muslim personal law exists. ${ }^{67}$ If there is a gap in the Recognition of Customary Marriages $\mathrm{Act}^{68}$ the traditional customary law can be applied. The Muslim personal law does not enjoy the same level of recognition. Legislation validating Muslim marriages will be an amendment or extension of the common law. If there is a deficiency in such an act the common law or customary law will have to be applied and not Muslim personal law.

It may be argued that Islamic law can be treated as foreign law. In terms of section 1(1) of the Law of Evidence Amendment Act ${ }^{69}$ the law of a foreign state may be recognised by the courts insofar as such law can be readily ascertained and with sufficient clarity. The parties who want to apply a different legal system than the common law or customary law will have to make a clear choice that foreign law should be applicable. ${ }^{70}$ Based on the definition of a "Muslim marriage" in the Draft Bill it can be argued that Islamic law is foreign to the South African

(s 1(x)(j)), which is wide enough to be similar to the irretrievable breakdown of the marital relationship as required by the Marriage Act and Recognition of Customary Marriages Act.

$62 \mathrm{~S} 6$.

63 Ibid.

64 Bakker 2004 THRHR 638.

65 Van Schalkwyk 2003 De Jure 326.

66 Law of the indigenous people of South Africa.

67 Ss 39(2)-(3) of the Constitution of the Republic of South Africa, 1996; Lourens "Inheemse reg: Aard en inhoud ingevolge die Grondwet" 1994 De Rebus 856; Himonga and Bosch "The application of African customary law under the Constitution of South Africa" 2000 SALJ 306; Pieterse 2000 De Jure 36. Muslim personal law does, however, enjoy indirect recognition in South Africa. The consequences of Muslim marriages are recognised by legislation and court decisions as discussed above. It might even be argued that due to the indirect recognition of Muslim marriages, Muslim personal law has become part of South African law. In Ismail v Ismail 19831 SA 1006 (A) (1025D-E) Trengove JA stated that "if a polygamous relationship is regarded as void on the ground of public policy, the custom or contract which flows from such a relationship is also vitiated". From this it follows that if the custom or contract which flows from such a relationship is recognised then the relationship is by implication recognised.

68120 of 1998.

6945 of 1988.

70 Scott and Dirix "Have your cake and eat it" 2004 Stell LR 335. 
legal system and may therefore be recognised in accordance with section 1(1) of the Law of Evidence Amendment Act, provided that the parties made a clear choice that Islamic law should apply to them. A marriage in accordance with legislation recognising Muslim marriages should qualify as such. ${ }^{71}$

It is, however, preferable to expressly provide for recognition of Islamic personal law in South Africa. Rautenbach proposes an act similar to the Indian Muslim Personal Law (Shariat) Application Act 26 of $1937 .^{72}$ The Act provides for the application of Muslim personal law to specific areas listed in the Act. Such an Act can expressly apply Muslim personal law to Muslim marriages. She proposes that the act does not need to contain substantive provisions of Muslim personal law. The substantive provisions can be developed by the courts or the legislature. If Muslim personal law is recognised by a general act it would be subject to the Bill of Rights. Discriminating practises can then be struck down by the court. $^{73}$

The Constitution provides the courts with the power to develop the common law and customary law in accordance with the Bill of Rights. ${ }^{74}$ No mention is made of any other religious or cultural systems that may be recognised by section 15(3) of the Constitution. The courts will therefore not have the power to develop Muslim personal law. The court may only declare a rule of Muslim personal law unconstitutional but cannot develop the rule in accordance with the Constitution. The void in Muslim personal law can only be filled by means of legislation or the development of the common or customary law. ${ }^{75}$

An argument against the general recognition of Muslim personal law is that limited resources regarding Muslim personal law exist in South Africa. ${ }^{76}$ It is further hazardous to leave the development of Muslim personal law in the hands

71 "Muslim marriage" is defined in s 1(xviii) of the Draft Bill as: "a marriage between a man and woman contracted in accordance with Islamic law"; see Prinsloo "Regspluralisme, 'n menseregte-akte en die interne aanwysingsreg" 1990 De Jure 360. It would however be advisable that the parties indicate which school of Islamic law should be applicable to their marriage. If the parties did not agree on the applicable school a similar approach to that of s 1(3) of the Law of Evidence Amendment Act 45 of 1998 could be followed. S 1(3) contains choice of law rules concerning the choice of law applicable in indigenous law. The same principles can be applied to determine the applicable law that needs to be applied in the case of Muslim marriages. This section states that if the parties did not agree on the system of indigenous law to be applied, the indigenous law which applies in the place where the defendant or respondent resides or is employed or does business should be applied. If two or more systems are applied in the area the court should apply the law of the tribe the respondent or defendant belongs to. These rules can however be simplified in the context of marriage law. Where the parties did not agree on the school applicable and do not belong to the same school then the school of the Imam conducting the marriage should be applied, if it is conducted by someone else than an Imam then the principles of the most prominent school in the area where the parties concluded their marriage should be applied.

72 "Some comments on the current (and future) status of Muslim personal law in South Africa” 2004 (2) PER 20-21 http://www.puk.ac.za/fakulteite/regte/per/issues.html (accessed on 28/05/2008).

73 Ibid.

74 S 39(2).

75 See Rautenbach 2004 (2) PER 22 and Rautenbach and Du Plessis "The extension of the dependant's action for loss of support and the recognition of Muslim marriages: The saga continues" 2000 THRHR 302.

76 Rautenbach 2004 (2) PER 22. 
of the judiciary and legal practitioners with inadequate knowledge regarding religious legal systems. ${ }^{77}$ The Draft Muslim Marriages Bill proposes that a Muslim judge should hear matters concerning Muslim marriages. Such a judge should be assisted by two assessors with expert knowledge on Islamic law. Provision is made for the appointment of practicing Muslim advocates and attorneys with at least ten years experience in practice to preside over matters concerning Muslim marriages if no judge is available. ${ }^{78}$ More resources should be provided for the education of legal students in religious law. The lack of resources did not prevent the legislature from passing the Recognition of Customary Marriages Act into law. ${ }^{79}$

Instead of a general Muslim personal law act, another option is to codify Muslim personal law. ${ }^{80}$ Although codification will create legal certainty it will also create an impression that Muslim personal law is a rigid set of rules that is immutable and cannot be developed in accordance with social and economic change. ${ }^{81}$ When following a conservative approach towards Muslim personal law this might be true in the sense that Islamic law is divine law and cannot be changed by the whims of mere mortals. The Reformists, however, take a more liberal view and acknowledge that Islamic law consists of secular and religious elements. Secular elements can be developed to meet social and economic demands.

\section{MODELS OF RECOGNITION}

When a legislating organ is faced with diverse legal systems its immediate reaction is usually to attempt to unify the systems. This is usually done by unification, integration or harmonisation of diverse legal systems. ${ }^{82}$ Should true unification be established it means that South Africa should recognise only one secular form of marriage. Unification would therefore merely mean that a diverse approach would be terminated and replaced by a uniform system of law. ${ }^{83}$ Rautenbach proposes a common secular marriage code for all South Africans. ${ }^{84}$ It might be possible to harmonise the basic requirements for marriage in general, but allow for diversification regarding the cultural and religious consequences of these marriages. However, if such an Act replaces the consequences of cultural or religious marriages it will merely be ignored. This will create nothing but paper law. On the African continent not one African state has successfully unified their

77 Ibid.

$78 \mathrm{~S} 15$.

79 Islamic law consists of clearly-demarcated written sources. The basic principles of Islamic law are similar in the different schools of thought although they differ in the application of the principles. The application is, however, clearly documented and it would not be more difficult to apply and teach than customary law. Although customary law is documented in various sources the dichotomy between unwritten "living" customary law and "official" written customary law complicates the application and teaching of customary law (see Bakker Huwelikspluralisme in Suid-Afrika (LLD-thesis UP (2003) 79-84, 218-222).

80 Moosa "Muslim personal law: To be or not to be?" 1995 Stell LR 417.

81 Bennett "The compatibility of African customary law and human rights" 1991 Acta Juridica 18.

82 For a discussion of these concepts see Bakker 2004 THRHR 626.

83 This is done by entertaining the dominant system and abolishing the so-called subordinate system.

84 Rautenbach 2004 (2) PER 26. 
diverse family law systems even though they have been trying for decades. The SALRC proposed to harmonise customary law with common law. ${ }^{85}$ The result of their investigation into customary family law - the Recognition of Customary Marriages Act - is however far removed from a harmonised result. The Recognition of Customary Marriages Act integrates customary marriage with civil marriage. The consequences of a customary marriage and divorce procedures were replaced by that of a civil marriage. ${ }^{86}$ The result is mere paper law. The author is of the opinion that the indigenous tribes in rural areas still live in accordance with traditional customary law as it was prior to the Recognition of Customary Marriages Act. ${ }^{87}$

The author is of the opinion that diversity should be maintained through legal pluralism. Legal pluralism is a factual situation associated with social diversity. ${ }^{88}$ Legal pluralism will exist for as long as social diversity exists. Rules or laws are not only created by the state alone. ${ }^{89}$ Communities will live in accordance with their personal law system regardless of whether it is recognised by the state or not. Muslim family law is practiced in South Africa regardless of nonrecognition by the state.

The principal argument against legal pluralism is the complexity of a pluralist system. It is argued that pluralism places too much strain on jurists, especially judges who were not trained in all the personal law systems of the country. This will lead to legal uncertainty. ${ }^{90}$ A pluralist system will also need a set of rules to determine which system is applicable. However, Prinsloo states that the situation must not be exaggerated:

"With a proper system of choice of law norms and jurists who have respect for and interest in all the legal systems of the country, problems should not be insurmountable. It is doubtful whether the number of legal rules in a legally pluralistic developing country exceeds those in a highly developed country with a single legal system, but with increasing Acts and regulations." 91

\section{CONCLUSION}

The unification of marriage law is not a feasible option. Legal pluralism will exist for as long as cultural and religious diversity exists. ${ }^{92}$ Before Muslim family

85 SALC Project 90 on the harmonisation of the common law and indigenous law (1999) 8.

86 In the case of customary marriages entered into after the Recognition of Customary Marriages Act was promulgated.

87 A customary marriage can only be dissolved by a court which is contrary to the traditional position that a customary marriage is dissolved in an informal manner by returning lobolo. There is no statistical information available of how many customary marriages are dissolved by the courts. The author is of the opinion that very few customary divorces are done in this way. Most divorces are still conducted in an informal manner. In Mabuza v Mbatha 20034 SA 218 (C) the defence witness was an expert and chief advisor to the Matsamo Tribal Authority Council in Mpumulanga Province, he practised in customary law for 22 years and was associated with the Matsam Tribal Authority in Nelspruit, yet under cross-examination he acknowledged that he did not know of the Recognition of Customary Marriages Act (paras 21 and 23).

88 Griffiths "What is legal pluralism?" 1986 J of Legal Pluralism 39.

89 Ehrlich Fundamental principles of the sociology of law (1936) 24-25.

90 Van Reenen "The relevance of Roman (-Dutch) law for legal integration in South Africa" 1995 SALJ 298; Woodman "Legal pluralism and the search for justice" 1996 JAL 161.

91 Prinsloo 1990 CILSA 328.

92 It might be possible to codify similar marriage requirements such as marriageable age and general issues regarding consent. 
law can apply in South Africa Muslim personal law should be recognised by a general act specifying the areas of application. ${ }^{93}$ If a party elects to marry in accordance with the Muslim Marriage Act it will be clear from this action that Muslim personal law should apply. Problems regarding choice of law might however be more evident in other areas of the law, for example the law of succession. If the parties marry in accordance with the Muslim Marriage Act they will automatically elect that Muslim personal law will apply to marriage-related issues.

If a cross-cultural approach to human rights is followed it cannot merely be argued that Muslim marriage law is fundamentally opposed to the Bill of Rights and can therefore not be recognised. Muslim marriage law should be generally recognised. Where the principles of Muslim marriage law are indeed opposed to the Bill of Rights such principles should be developed in line with the spirit and purport of the Constitution. The power of courts to develop Muslim personal law could be included in the general Act recognising Muslim personal law. Merely striking down principles that are in conflict with the Bill of Rights is counterproductive.

93 Choice of law should not be a problem in determining the application of marriage law. 